\title{
BRAND IMPACT ON THE COMPANY'S FINANCIAL PERFORMANCE
}

\author{
Assoc. Prof. Jugoslav Aničić, PhD \\ "Union-Nikola Tesla University", Faculty of Entrepreneurial Business, Cara Dusana 62-64, \\ 11000 Belgrade, Serbia, ajugoslav@yahoo.com \\ Assoc. Prof. Aleksandar Majstorović, PhD \\ "Union-Nikola Tesla University", Faculty for Real Estate Management, Cara Dusana 62 -64, \\ 11000 Belgrade, Serbia, majstorovicaleksandar@gmail.com \\ Vesna Petrović, PhD
}

Poenkareova 55 B, 35250 Paracin, Serbia, al.petrovicpn@gmail.com

Dušan Aničić, master

DSN Consalting, Zaplanjska 86 v, 11000 Belgrade, Serbia, anicic.dusan@yahoo.com

\begin{abstract}
There has been a major change in the company's assets structure after the year 2000, which is reflected in the massive decline of fixed assets participation and the increase in the intangible assets participation. This change was not appropriately accompanied by accounting standards and principles that are still adjusted to the capital assets value. Hence the accounting value of the many companies' assets is far from its market value, which is negatively reflected on rendering business and investment decisions, and, ultimately, on the business activity results. Special attention is devoted to branding products and services in the contemporary businesses, as a model forlong-term competitive market advantage acquisition and business and financial performances improvement.
\end{abstract}

Key words: intangible assets, brand, financial performances, business

\section{Introduction}

At the beginning of the XXI century, the economic environment changes are more rapid and intensive than they have ever been before. The individuals' and organizations' constant need to keep up with the changes, and be ahead of competition caused a drastic change in views and understandings of the values and goals that companiesrepresent to their Managing Board. According to the empirical indicators, by the year 2000, fixed assets comprised the most significant share of most companies' assets and their acquisition was the primary goal in the business. Our, contemporary economic time is marked by the radical changes at the market (local, domestic, regional, global), and consequently, investing in the intangible assets represents the basis for making profit and successful positioning companies in the market.

Contemporary environment is characterized by intensive company knowledge in the field of high information technology, automobile, pharmaceutical, and other branches of industry. In the industrial era of economy, companies created values through application of tangible assets (company buildings, equipment and installations, land, different kinds of stocks, etc.). The company value is today estimated not only according to the total turnover, market participation or the ratio between the market price and the net income per stock, but according to intellectual capital such as branding, customer loyalty, organizational culture, etc. Traditional accounting is based on indicators such as rate of return on capital or income per stock, but this and similar indicators do not manifest enough about the company performance to the investors.

The fixed assets acquisition and creation is a rather costly process, but what is even more complex is its management in an adequate manner with the aim of makinga desired gain. The best instance for that are the enormous investments the companies in the field of high technology make in order to acquire ownership over small companies, above all, because of fixed assets they wish 
to obtain, such as the systems that are available to the company, consumer relations, technicians' knowledge and expertise, etc. Although intellectual assets are not tangible and visible, they can be managed, and consequently, they need to be adequately estimated. Analysts and consultants have developed appropriate standards designed in order to express more accurately the brand and other sorts of intangible assets value, in order to compensate for the lack of the traditional accounting and financial report.

\section{Role and importance of company's intangible assets}

Fixed assets have always been in the middle of the economic scene, as a basis of all transactions and primary means of business activity. Changes that occurred in the last years and the current state of the global industry indicate to the growing significance of intangible assets in companies' property. Issue of intangible investments is current and important, especially in the era of developed information technologies, which is primarily characterized by the speed of the quantitative and qualitative changes. The global economic crisis, hitting the global economy, has had an influenceon all elements in the economic environment, and the intangible investments as well, they have become more important in the years of recession.

The intangible assets investment problem is particularly popular because it is in the field of the knowledge economy, which is based on the two main resources, knowledge and information. Being successful means constantly investing in development and professional training of the human resources, owning knowledge, expertise and information, and knowing how to use them in the right moment. Intangible resources investment is popular primarily in postcapitalistic societies, as highly developed ones, but also in the post-socialistic society that undergoes a period of transition and is preparing to enter the global market.

Tendencies of expenses increase in research and the intangible assets development, increase in investment value in acquisition of intangible property through the common investments (acquisitions) and benefits that such investment brings, with obvious advantages that employer is provided with when using intangible property as opposed to the fixed propertyhave been noted in the contemporary businesses in the previous years. Besides, the income that intangible investments provide to the economy subject that owns them, are rising.Backwardness of the traditional indicators used for the intangible property evaluation is pointed out, and there is a growing need forcreation of the new evaluation system for intangible investments. Furthermore, problems of inadequate enlightenment and displaying of intangible property according to the accounting standards, rules and guidelines that are imposed by the International accounting standards and that economy subjects are bound to apply while acknowledging and evaluating intangible property.

At the beginning of the XXI century, organizations with extensive knowledge, have become substitute for capital intensive companies, and knowledge and information are invaluable for successful business operating, stationing and survival at the competitive global market. Investments in intangible assets are mostly present in organizations of the developed world, but they are also necessary in companies in developing countries, increasing their possibilities of entering the developed global markets. Owning relevant information, knowledge and expertise represent the source of competitive advantage at the market determined by globalization, competition and openness.

Information technology development has accelerated the process of research and development of intangible assets. Investing into companies' intangible assets is 
conditioned by growing consumer expectations concerning quality, quantity and consistency of their products, services and ideas. Innovation process in the contemporary economy imposes on companies the need to protect their discoveries through patents, licenses, or some other forms of intangible assets.

On the other hand, the accounting is based on traditional principles created according to needs and model of fixed assets, therefore problems concerning accounting treatment of intangible investments occur in reality. Valid accounting standards regulating investments into intangible assets need to be brought up to date by new financial and non-financial indicators with the aim of showing more realistic financial reports. Intangible investments problem is present the most in the field of economy, law and administration, but it can also be said that it affects all elementsconnected to the economy, because there is no branch in which research and development, expertise, knowledge and information aren't present, and where they don't represent a crucially important element ofprogress and growth.

Information era has brought along a number of changes that are becoming more visible in the economic environment. The most important resources are becoming the ones that are physically intangible, and intangible assets are becoming the source of competitive advantage. The most valuable intangible assets relate to the consumer relations, expertise and knowledge of the employees, information technologies and the organizational culture open to innovations, problem solving and the overall advancement of organization (Kaplan et all, 2000). Successful, companies with extensive knowledge operating in business in fields of high technologies, science, Internet and service sector, as well as a smaller number of companies from the field of building materials, gas, chemicals, wide consumption products and retailing production, do business within systematic, carefully planned and executed innovative processes (Lev, 2000).

Intangible investments are acknowledged and evaluated in accordance with the, IFRS 38- Intangible assets, IFRS 23- Renting expenses, IFRS 36-Property value and the other relevant standards (Group of authors, 2010) diminution. Intangible investments, i.e. assets, represent non-monetary property that can be identified even though it does not have a physical feature. According to the International accounting standard 38Intangible investments, asset represents a resource of an economic subject:

- that controls economy subject and is a result of previous events (its purchase or production) and

- from which economy subject expects influx of future economic benefits.

Intangible assets can be observed from both legal and market perspective. The first group comprises of intangible assets such as patents, licenses, author rights, trademarks, goodwill; while the other group would consist of knowledge, know how, activities related to the cooperation with the clients, etc. Intangible assets observed from the legal aspect are called, in one word, intellectual property and are subjected to legal protection, while the other category is characterized by efficiency and efficacy in operating, productivity, customer satisfaction, market value of the business association, stock value at the market.

There have been major changes in the size and importance of intangible investments at the corporative level in the last three decades. According to that, for example, the value of intangible investments has increased in the USA more than five times in the last twenty years. The relation between market and bookkeeping value (M/B indicator) ${ }^{1}$ for companies that in

${ }^{1}$ Market value/Book Value Ratio (M/B ratio) indicator of market and bookkeeping value relation 
index calculation S\&P $500^{2}$ exceeded 6,0 , thereby indicating that five of every six United States dollars (USD) of the corporative market value are missing in the balance sheet (Lev, 2000).

Value of the share capital invested in the intangible assets in the USA has reached the amount of 5 thousand billion dollars (USD) which is almost half of the market value of all of companies in the USA (Hand, Lev, 2004). Capital owners, managers and leaders, especially the ones that make decisions concerning investments, have to fully deal with this indicators, considering the fact that intangible assets have become an important, and growingly significant part of assets of many large corporations. Relation between intangible and fixed assetswas $38 \%$ to $62 \%$ for the benefit of fixed assets in 1982, while in 1992 , that relation was $62 \%$ to $38 \%$ for the benefit of intangible investments. Investment expenses for intangible assets have increased from $4 \%$ of the Gross Domestic Product in the USA in 1997 to $10 \%$ in 2006 (Nakamura, 2009).

\section{Place and role of brand in contemporary market conditions}

Companies that, in contemporary market conditions, tend their business operating not to be a short-term project need to build strong and successful brand. Brand is one of the key factors of a successful business operating, and creation and development of a strong brand should be imperative in every company's operating. We can see different definitions of brand in the professional literature but basic understanding of this phenomenon is in its definition as a psychological, emotional category. Namely, brand represents consumer, i.e. byer and branded product relationship. That is a relation created in the consumer's consciousness and it determines their behavior in various ways, and affects their buying decision.

\footnotetext{
${ }^{2}$ Standard \&Poors 500 stocks Composite Average (S\&P 500) - index which comprises of 500 highly qualified companies, mostly seated in the USA

Basic, primary factor of brand success at the market are its consumers, or things that what they know, feel and think about a certain product. Brand categorization is nothing but differentiating brand according to its geographical distribution, type of company's activity, life cycle, values, length and division in other various grounds. Brand characteristics or features, i.e. what acustomers connect the brand name with, determine its successfulness and direction of its development in a certain business area of companies operation.

In the last decade, brands have become the main instrument in the market domination and making profit. Brand is a product perception in a consumer's consciousness; it is created through experiences consumers have with the product. Brand is defined in various ways. David Aacker's definition of a brand is: "Brand is a name, a term, a design, a symbol, or some other characteristics that identifies the good, or a service of a salesperson, differentiating them thus from the other salespersons". Brand represents a name, a term, a mark, a symbol, an association, a trading mark or a design, and it is used for identification or differentiation of products or producers' services or a group of producers from the competition. Brand owns functional or emotional elements which createconsumer product, i.e. services relationship.

Consumer product, i.e. services relationship is emphasized in most of brand definitions: "Brand represents a lot more than a name, a term, a mark or a symbol, or any other characteristic, at the 21.century market. It represents a relationship that is significant both for companies and consumers. It represents everything that a consumer is and believes in. Thus, brand enables a consumer to take its desirable place in the society (Kotler, Keller, 2008)'”. According to Leslie de Chernatony and Malcolm McDonald, a successful brand is a product, a service, a person or a place that can be identified and that are increased in such a way that a consumer or user gain relevant, 
unique additional values that satisfy their needs the most. The brand successfulness results in the possibility that these additional values preserve the brand in relation to the competition (Chernatony, McDonald, 2011).

A trade mark represents the producer's or tenderer's obligation that their product would have certain features, usefulness, services, that it would, above all be of certain quality standard. Trade mark, along with the product enables the satisfaction of the needs, i.e. fulfilling aimed function. However, their basic and the most important function is to make a certain product different from the rival (Laketa, 2009) ones. David F. Alessandro (2001) in the forefront of a brand definition places all the associations the consumers have about a certain company: brand represents everything a consumer thinks of when they hear a company's name.

It wasn't until after the World War II, in America, that brand as we see it today, was created, and for multiple reasons. Industrial capacities created during the war with the aim of satisfying military needs, were redirected to satisfying man's consumer needs, thereby a huge number of new products that had the need to differentiate from one another, appeared. An average citizen's economic power grew, enabling them to be able to afford far more goods for themselves, shopping became trend, hoarding of goods and products became a cure and consolation after the war depression and dearth.

Distribution of mass media has won a critical group of followers (buyers, listeners, watchers) and thus covered a circle of potential customers. In this circumstances, advertising agencies became essential in mediation between sellers and buyers, which were, in the overall race for the part of the audience, coerced into creation of new spaces for advertising as well as new spaces for drawing attention. Theoretically developed semiology and psychology gave access to methodological principles of useful communication in advertising. Postmodern in art, and postindustrial revolution, i.e. final transfer from trade in goods to trade in information (information society, electronic era) - have created a brand as we know it today.

In the 1980's some of the strongest producers in the world began to stagger. Corporations were too big: they owned too much, hired too many people, and were overwhelmed from too many 'sides'. The production process itself: running the factory, responsibility for thousands of workers with full working hours and fulltime employment, began to seem less like a shortest way to success, and more like something unreliable. At the same time, new kind of corporations appeared as a rival to the traditional big producers, looking for its place in marketing. Those were Nike and Microsoft, and later Tommy Hilfiger and Intel. These pioneers bravely held opinion that production of goods was only a secondary part of their operations and that owing to the recent victories in freeing the trade and labor force law reform they are now able to have their goods produces by producers by contract, many of which are 'across the pond'. Their actual job is not production, but marketing, and this formula turned out to be extremely profitable.

Brands have major functions for the company, too. Firstly, they simplify handling products and their monitoring. Brands help organize supply data bookkeeping data. Through brand, a company can legally protect unique features or aspects of a product (Constance, 1995). Brand name can be protected by registered trademarks; producing processes can be protected by patents; packing can be protected by authors' rights and design. Cited laws to intellectual property enable company to freely invest in brand and make profit from the just as valuable assets.

Brands can represent synonym for a certain quality level, so that satisfied customers can choose that product (Tulim, 1998) again. 
Brand loyalty enables predictability and demand certainty to a company, and it also creates boundaries that make it more difficult for the other companies to get in the market. Loyalty can stimulate readiness to pay a higher price. Competition may be able to easily copy production processes and product design, but they surely wouldn't be able to easily compete with permanent impressions in the consumers' and organizations' consciousness which are created through years of marketing activities and experiences with a product. From that point of view, branding represents a powerful means of ensuring rival advantage.

Brands today represent an extremely worth property of companies which can affect consumers' behavior, which can buy and sell, and which ensures certain future profits for its owner (Bymer, 1991). Starting from the middle of 1980's when there was an industry growth and numerous mergers and acquisitions, huge amounts were paid for brands. On one side, justifications for higher price were assumptions thatextra profits would be derived and made through brand, and on the other side, those were huge difficulties and expenses of creating a similar brand from the very beginning. On the stock market it is considered that strong brands affect better income and profit performances of companies, which creates higher value for shareholders too. Higher management has lately been showing interest in brands, which is mostly outcome of the exact cited financial reasons (Keller, 2000).

\section{Financial brand evaluation}

All participants at the market tend to create a prestigious brand and loyal customers but there is many more of those whose efforts to reach these goals ended unsuccessfully. Brand is used in order to identify products and services, as well as producers and sellers. Purchase of famous brands brings along lower risk of wrong purchase, but it also establishes specific emotional relations to the brand, 'connection' with other people using the same brand, etc. What arises from that is that 'extra value' that consumer gains by purchasing a certain brand is a consequence of an entire line of benefits that a brand offers to a consumer. On the other hand, it is evident that companies themselves have major benefits, therefore, more successful companies are the ones that have stronger and more famous brands in their portfolio (Veljkovic, 2010).

From the manager's perspective, brand impact can be seen from two basic points of view Veljkovic, Djordjevic, 2010):

1. Impact from the aspect of value creation for consumers which is considered through the brand impact on increased total created and delivered value consumers gain by purchasing certain products and services. This point of view implies analysis to what extent brands increase value to consumers and have impact on purchase size growth or they enable price growth considering that they increase total sum of created and delivered value.

2. Impact from the aspect of economic value creation for companies. Brand has a significant impact on companies' performances that are measured in companies' nonmaterial values (goodwill). Companies that have the highest market value are certainly the ones with strong and recognizable brand. Volume of sales and economic value are directly connected with consumers, bearing in mind that volume of sales is a result of number of consumers and size of purchase. Profit estimation, is largely, besides from know-how, licenses ownership, exclusivities for certain markets, etc. connected to the brand size.

Transferring from industrial into information, or knowledge based society, is largely changing the basis of companies' 
future growth and development. A huge number of companies realizes that knowledge is the most significant source of social and economic development, and most powerful weapon for gaining competitive advantage. In these circumstances, a question of adequate way of brand evaluation as part of intangible assets arises. Reasons for intangible assets evaluation are commercial, accounting, tax, etc. needs, such as (Contractor, 2001): selling a company, managers, acquisitions, purchase, selling or auctioning off separable assets such as brand, patents, property rights, data bases or technology, tax liability calculations, strategy alliances creation, research and development managing, collateral financing, etc.

Adequate evaluation of brand value will enhance external financial report through which it will lower differences between company's bookkeeping and market value. Besides, companies will have data of real value of their assets which will improve additional capital drawing and have positive influence on potential investors. Managing needs within a company impose need for brand value estimation, because brand and other intangible assets management requires more attention and more complex approach, as opposed to fixed assets management. Adequate intangible assets management provides feedback to the management for making business decisions and business enhancement altogether.

From company's point of view, main reasons for intangible assets evaluation are(Holmen, 2005):

- evaluation can help company formulate business strategies in proper manner and enhance competitive advantages

- application of contemporary evaluation methods can bring to development of key performances indicators which will ensure fulfillment of developed strategy
- using nonfinancial means of intangible assets will contribute to establishing necessary stimulation systems and compensations of the employees

- purpose of intangible assets evaluation is also seeing effectiveness and efficacy of a companyto create additional values and attract valuable and necessary resources by using those assets, such as financial capital, competent employees, profitable consumers, etc.

In relation with brand value establishment, a huge number of methods for brand value calculation has been developed in recent years, and all methods can be divided into two groups:

1. Brand value according to the research on consumers attitude

2. Brand value according to the financial-market indicators analysis

The most famous models for brand value establishment through research on consumers' attitudes and behavior at the market are: Aacker's model for market brand value establishment, Brand Asset Valuator (BAV) model, Brand Conversion Model, Burke Brand Index Model, Brand Potential Index (BPI).

Models of financial brand value are based on expenses, future course discounting, comparing to companies that do not have a brand, on residual income, on selling, expanding and brand licensing options, as well as on combinations of some of afore mentioned methods and techniques. There are common steps in most of the combined models, such as prediction of future outcomes, calculating brand impact on making profit, profit value discount to a present value, etc. the most famous models from this group are Interbrand Methodology, Brand Finance Model, Model BrandDynamics, Advanced brand Valution (AVB). 
There is causal link between ways of calculating brand value because models about consumers' attitudes are often incorporated in models for calculating brand value according to financial-market indicators, because brand value is also determined according to basis of predicting and market position strength.

\section{Conclusion}

Changes that occurred in the previous years at global level and current state of industry point to the growing significance of intangible property in company's assets. Investing into intangible assets is especially popular because it falls into the knowledge economy, which is based on two basic resources, knowledge and information. Elements of success are constant investment in development and professional training of human resources, owning knowledge, experience, information, and their application in the right moment. Traditional indicators used for intangible assets evaluation are becoming inadequate and there is a growing need for creation of new evaluation system for intangible investments. Problems of inadequate intangible assets revealing and displaying according to the accounting standards, and which private sectors are obligated to apply when acknowledging and evaluating intangible assets,are also getting significant attention.

In contemporary market conditions, companies that seek long-term successful business operation have to build strong and successful brand. Brand is one of key factors in business success, and creation and development of a strong brand should be an imperative in every company's operating. The most important element of success at the market are its consumers, i.e. what they know, feel and think about a certain product. Brands have become main means of marketing rule and making profit. That is why an adequate brand value evaluation which will enhance external financial reporting and have effect on lowering the differences between bookkeeping and market value of a companyis necessary. Companies will gain trustworthy data of their assets' actual value, which will have a positive effect on potential investors, it will provide efficient company management and business enhancement altogether.

\section{References}

Bymer, Ch., „Valuing Your Brands: Lessons from Wall Street and the Impact on Marketers," ARF Third Annual Advertising and promotion Workshop, 5-6 February, 1991.

Chernatony L., McDonald M. Creating Powerful Brands, Taylor \& Francis Group, London and New York, 2011

Contractor, J., F., (2001), Valuation on Intangible Assets in Global Operations, Greenwood Publishing Group, Inc, p. 4

Constance E. Bagley, Managers and the Legal Environment: Strategies for 21st Century, second edition. Cincinati, $\mathrm{OH}$ West Publishing, 1995.

David F. D 'Alessandro, Brand warfare, McGraw Hill, 2001.

Group of authors , Handbook on application of schedule framework in accordance with MRS/MSFI" ,Economic Counsellor, Beograd, 2010.

Hand, J., Lev, B., Intangible Assets, Oxford University, 2004, p.4

Holmen, J., (2005), Intellectual Capital Reporting, Management Accounting Quarterly, Vol 6, No 4, str. 2

Kaplan, R., Norton, D., Having Trouble with Your Strategy? Then Map It! Harvard Business Review, September-October 2000.

Keller, K. L., „, The Brand Report Card,” Harvard Business Review (JanuaryFebruary 2000), 147-157. 
Kotler P.,Keller L. (2008) Marketing management, 12.issue, MATE 1.1.c.., Zagreb.

Laketa, M., Marketing in function of company development, NarodnaknjigaAlfa, Beograd, 2009.

Lev, B., New Accounting for the New Economy, Working paper, New York University, Stern School of Business, 2000, p. 4.

Lev, B., New Accounting for the New Economy, Working paper, New York University, Stern School of Business, 2000, p. 2.

Nakamura, L., Intangible Assets and National Income Accounting: Measuring a scientific Revolution, Working paper No. 09-11, Federal Reserve Bank of Philadelphia, 2009, p. 33

Tulim, E., "Brand Equity as a Signaling Phenomenon," Journal of Consumer Psychology 7, no. 2, (1998), 131-157.

Veljković, S. (2010) Brand management in contemporary market conditions, CID, Faculty of Economy, Beograd

Veljković, S., Đorđević, A.,(2010) „Brand value for consumers and companies", Marketing, Vol. 41/1. Beograd.

http://wwww.allaboutbranding.com 